\title{
Rozmowa Nowotworów z Profesorem Jackiem Jassemem — ustępującym Przewodniczącym Polskiego Towarzystwa Onkologicznego
}

\author{
Prof. Edward Towpik: Proszę o bilans osiąg- \\ nięć tej - najbardziej dynamicznej w historii \\ - kadencji Zarządu Polskiego Towarzystwa \\ Onkologicznego. Zacznijmy od spraw we- \\ wnątrzorganizacyjnych.
}

Prof. Jacek Jassem: Pierwsze miesiące kadencji poświęciliśmy na uporządkowanie spraw organizacyjnych i finansowych, bo bez tego żadne towarzystwo nie może sprawnie działać. Zaczęliśmy od zweryfikowania liczby naszych Członków we wszystkich Oddziałach. Zmieniliśmy statut PTO, przystosowując go do stanu prawnego państwa

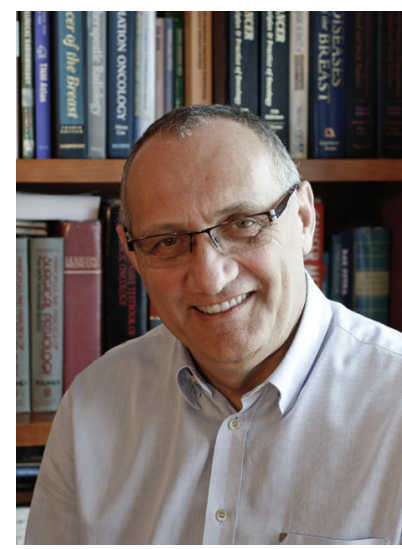

Prof. Jacek Jassem oraz współczesnych standardów. Podjęliśmy działania naprawcze w kilku mniej aktywnych Oddziałach oraz stworzyliśmy trzy nowe: na Podkarpaciu, w Koszalinie i w Kielcach. W efekcie zwiększyliśmy swoje grono o kilkaset osób: jest nas obecnie 1319.W czasie tej kadencji osobiście odwiedziłem 15 spośród 16 Oddziałów PTO, spotykając się na miejscu z ich Członkami. Znacznie poprawiliśmy stopień opłacania składek członkowskich, do czego w dużym stopniu przyczyniło się wprowadzenie prostego, elektronicznego systemu wnoszenia tych opłat. Członkowie PTO korzystają obecnie z szeregu przywilejów, w tym bezpłatnej prenumeraty czasopisma Nowotwory J Oncol w drukowanej i elektronicznej wersji, zniżkowych opłat rejestracyjnych na organizowanych przez nas zjazdach i konferencjach naukowych, możliwości ubiegania się o dofinansowanie szkoleń i wyjazdów naukowych oraz o naukowe granty i nagrody Towarzystwa. Uporządkowaliśmy zarządzanie finansami poprzez ujednolicenie sprawozdań finansowych i przeniesienie kont poszczególnych Oddziałów do jednego banku. Co ważne, bardzo poprawiliśmy sytuację finansową, co pozwoliło nam szeroko rozwinąć statutową działalność. W ostatnim czasie, dzięki inicjatywie Kolegów z łódzkiego Oddziału PTO, udało nam się przygotować w formie książkowej i elektronicznej pełną bazę adresową naszych Członków.
Prof. ET: A działalność w zakresie edukacji?

Prof. JJ: Działalność edukacyjną realizujemy w formie wydawnictw, spotkań, kursów, szkoleń, sympozjów i kongresów naukowych, zarówno w poszczególnych Oddziałach PTO, jak i na szczeblu krajowym. W ostatnich latach aktywność ta bardzo wzrosła zarówno pod względem liczby tych wydarzeń, jak i ich uczestników. Dużym sukcesem naukowym, edukacyjnym i organizacyjnym był zorganizowany przez nas we współpracy z 26 innymi towarzystwami naukowymi III Kongres Polskiej Onkologii, który odbył się w 2010 roku we Wrocławiu z udziałem ponad 1200 osób i pod patronatem Prezydenta RP. Oprócz grona czołowych polskich onkologów mieliśmy zaszczyt gościć tam wielu wybitnych wykładowców z całego świata, na czele z laureatem Nagrody Nobla Haraldem zur Hausenem. Wielką frekwencją cieszyły się tam poranne sesje edukacyjne. Bardzo dobrze przyjęta została także zapoczątkowana w 2013 roku coroczna Konferencja Naukowa naszego czasopisma Nowotwory J Oncol — „Debaty Onkologiczne”. W Newsletterze PTO zamieszczamy przegląd ważniejszych doniesień naukowych ze świata, z promocją prac polskich autorów. W naszym czasopiśmie Nowotwory Journal of Oncology kontynuujemy dział „Journal Club", upowszechniający najważniejsze doniesienia naukowe $\mathrm{w}$ dziedzinie onkologii — redagują go od lat moi młodsi Koledzy z Kliniki, za co chciałbym im tutaj serdecznie podziękować. Inicjujemy opracowania eksperckie dotyczące wybranych aspektów diagnostyki i leczenia nowotworów, np. zaleceń dotyczących diagnostyki PET w onkologii, systemowych metod leczenia nowotworów płuca i opłucnej czy opieki onkologicznej po zakończeniu leczenia. Współpracujemy z innymi towarzystwami i organizacjami. Czynnie uczestniczymy w szkoleniach lekarzy POZ w dziedzinie onkologii. Od 2 lat realizujemy duży ogólnopolski program edukacyjny 
„Akademia Żywienia w Onkologii", a w najbliższym czasie uruchamiamy kolejny — „Akademia Walki z Bólem”. Z naszą działalnością edukacyjną wychodzimy także do innych środowisk, np. do dziennikarzy zajmujących się sprawami zdrowia. Ogromnym zainteresowaniem cieszy się organizowana w tym roku już po raz czwarty "Letnia Akademia Onkologiczna" dla dziennikarzy. Czynnie uczestniczymy w spotkaniach organizacji pacjentów. Trwają przygotowania do inauguracji profesjonalnego portalu edukacyjnego dla społeczeństwa i chorych na nowotwory - na podstawie zawartych umów będziemy mogli skorzystać z zasobów podobnych portali: National Cancer Institute i American Society of Clinical Oncology.

Prof. ET: Proszę o przedstawienie działań na rzecz poprawy skuteczności zwalczania nowotworów w kraju.

Prof. JJ: Skuteczność polskiego systemu opieki onkologicznej mierzona wskaźnikami zdrowotnymi jest nadal istotnie niższa niż w innych krajach, także w tych o podobnym stopniu rozwoju gospodarczego. Działania w tej dziedzinie stanowiły zatem nasze największe wyzwanie w bieżącej kadencji i pozwolę sobie omówić je szerzej. Już w pierwszych miesiącach zapoczątkowaliśmy projekt zatytułowany "Czas na onkologię", którego celem była poprawa skuteczności systemu opieki onkologicznej w Polsce. Rozpoczęliśmy od przeprowadzenia analizy czynników warunkujących skuteczność polskiego systemu opieki onkologicznej na tle innych krajów. Jej efektem była monografia pt.„Biała Księga. Zwalczanie raka jelita grubego i raka piersi w Polsce na tle wybranych krajów europejskich — analiza zasobów opieki onkologicznej i czynników warunkujących sukces", która ukazała się w marcu 2011 roku. Raport dotyczył przede wszystkim dwóch rodzajów nowotworów, ale wiele zawartych w nim danych i końcowych wniosków miało wymiar bardziej ogólny.W październiku 2011 roku ukazała się druga część tego opracowania, zatytułowana „Strategie działań dla poprawy skuteczności zwalczania raka piersi i raka jelita grubego w rekomendacji PTO". Zwróciliśmy w niej uwagę na konieczność systemowego, a nie cząstkowego podejścia do poprawy skuteczności zwalczania nowotworów w Polsce oraz wyodrębniliśmy główne cele działań w tym kierunku. Obydwa raporty zostały zaprezentowane podczas publicznych debat z udziałem przedstawicieli Ministerstwa Zdrowia i NFZ oraz dziennikarzy zajmujących się tematyką medyczną. Wyraziliśmy równocześnie zdecydowany postulat przyznania onkologii priorytetu w polityce zdrowotnej państwa. Kolejnym studyjnym projektem był raport o stanie polskiej radioterapii, który przygotowała na nasze zlecenie warszawska Uczelnia Łazarskiego.

Nasze działania zbiegły się z zaleceniami WHO dotyczącymi stworzenia całościowych, narodowych planów walki z rakiem, a także z inicjatywą Komisji Europejskiej pt.
"European Partnership for Action Against Cancer (EPAAC)”, zalecającej wszystkim krajom Unii Europejskiej opracowanie takich planów do końca 2013 roku. Zakłada się, że ich wdrożenie powinno doprowadzić do zmniejszenia do 2020 roku o 15\% obciążeń związanych z nowotworami (cancer burden) oraz o 70\% - europejskich różnic w skuteczności leczenia nowotworów. W 2012 roku większość krajów europejskich realizowała już te zalecenia, podczas gdy Polska nie podjęła do tego czasu żadnych działań w tym kierunku. W tej sytuacji w październiku 2012, w czasie III Kongresu Onkologii Polskiej, wraz z innymi naukowymi towarzystwami onkologicznymi zaapelowaliśmy do Ministra Zdrowia o pilne opracowanie narodowej strategii opieki onkologicznej w Polsce oraz o rozpoczęcie prac nad nowelizacją i kontynuacją Narodowego Programu Zwalczania Chorób Nowotworowych. W grudniu 2012, na zwołanym na prośbę PTO posiedzeniu Senackiej Komisji Zdrowia, przedstawiłem stanowisko Towarzystwa odnośnie kierunków zmian w organizacji polskiego systemu opieki onkologicznej. Naszym głównym postulatem było opracowanie Narodowej Strategii Walki z Rakiem jako drogowskazu w działaniach władzy publicznej oraz wszystkich osób i instytucji mających wpływ na zwalczanie nowotworów.

Do tych działań udało nam się zmobilizować niemal całe środowisko onkologiczne. W przeprowadzonym sondażu przeszło $80 \%$ lekarzy-onkologów wyraziło gotowość do poświęcenia prywatnego czasu na udział w pracach nad poprawą polskiego systemu walki z rakiem. Postanowiliśmy zatem podjąć je w drodze szerokiej oddolnej inicjatywy, na wzór kanadyjskiej Strategy for Cancer Control.

W kwietniu i czerwcu 2013 r., z udziałem szerokiego grona lekarzy, ekspertów w dziedzinie organizacji ochrony zdrowia i przedstawicieli organizacji pacjentów, zorganizowaliśmy dwie duże debaty programowe PTO poświęcone głównym kierunkom rozwoju polskiej onkologii.

W maju 2013 roku, przy naszym merytorycznym wsparciu, powstał Parlamentarny Zespół ds. Onkologii, skupiający posłów i senatorów zainteresowanych walką z rakiem w Polsce. Podczas kilku kolejnych posiedzeń Zespołu przedstawiliśmy zrzeszonym w nim posłom i senatorom najważniejsze problemy oraz propozycje rozwiązań w dziedzinie onkologii. Mamy więc w parlamencie silną grupę wspierającą nasze działania i liczymy, że podejmie ona niezbędne inicjatywy ustawodawcze. W dniu 18 grudnia ub. roku wystosowałem w imieniu Zarządu Głównego PTO list otwarty do Prezydenta, Premiera i Ministra Zdrowia, w którym zaapelowałem o zmianę obecnych zasad i zniesienie limitowania medycznych świadczeń onkologicznych. Postulat ten nawiązywał do rozpoczętych prac nad naszym strategicznym planem. Treść listu spotkała się z wielkim zainteresowaniem mediów, środowisk medycznych i przedstawicieli instytucji decydujących o polityce ochrony zdrowotnej. Podczas Konferencji Prasowej w Urzędzie Rady Ministrów 21 marca br. Premier 
i Minister Zdrowia przedstawili obietnicę zniesienia od stycznia przyszłego roku limitów na świadczenia onkologiczne. W grudniu 2013 roku przystąpiliśmy do ostatniej fazy prac nad Strategią Walki z Rakiem w Polsce na lata 2015-2024. Do współpracy nad tym projektem zaprosiliśmy Polskie Towarzystwo Onkologii Klinicznej, Polskie Towarzystwo Radioterapii Onkologicznej, Polskie Towarzystwo Chirurgii Onkologicznej, Polskie Towarzystwo Patologów, Polską Unię Onkologii oraz Polską Koalicję Pacjentów Onkologicznych. Już w trakcie prac do tego grona dołączyły Kolegium Lekarzy Rodzinnych w Polsce oraz Polskie Towarzystwo Medycyny Rodzinnej. Powołaliśmy 10 tematycznych, wieloosobowych grup roboczych, koordynowanych przez znakomitych ekspertów.W drodze konkursu ofert wyłoniliśmy doświadczoną firmę doradczą PwC (dawne Pricewaterhouse Coopers), która koordynowała całość prac. Funkcję sekretariatu i biura prasowego "Strategii" powierzyliśmy warszawskiej agencji Primum PR. Nieformalny patronat nad naszym projektem objął premier Donald Tusk. W ciągu trzech pierwszych miesięcy br. pracowało nad nim społecznie blisko 200 osób, reprezentujących ośrodki onkologiczne, uczelnie medyczne i organizacje pozarządowe, a także eksperci z dziedziny zarządzania, zdrowia publicznego, finansów i prawa oraz pacjenci onkologiczni. W ostatniej fazie prac uczestniczyli także przedstawiciele Ministerstwa Zdrowia i Centrali NFZ. Odbyło się ponad 20 spotkań i telekonferencji, w repozytorium projektu zgromadziliśmy 270 źródłowych dokumentów. Plon naszych prac przedstawiliśmy 10 kwietnia 2014 roku podczas III narady roboczej PTO, zamieszczając go równocześnie na specjalnej stronie internetowej www.walkazrakiem.pl. Obecnie projekt,"Strategii"znajduje się w fazie zewnętrznych konsultacji, a jego ostateczna wersja ukaże się w języku polskim i angielskim w czerwcu 2014 roku jako oficjalny państwowy dokument. Wierzę, że jego wdrożenie stanie się punktem zwrotnym w zwalczaniu nowotworów w Polsce.

Prof. ET: A jaki jest dorobek w zakresie rozwijania kontaktów międzynarodowych?

Prof. JJ: PTO wspierało liczne inicjatywy i projekty w zakresie międzynarodowej współpracy naukowej, a także indywidualne działania naukowe naszych członków. Wspólnie z partnerami amerykańskimi i dzięki nieocenionej pomocy naszego przyjaciela — George'a Handy'ego z Waszyngtonu, zapoczątkowaliśmy naukową współpracę z amerykańskimi jednostkami akademickimi, czego efektem jest kilkanaście dwustronnych i wielostronnych projektów. Odbywamy regularne spotkania naszego Konsorcjum podczas dużych kongresów po obu stronach Atlantyku. Współpraca ta obejmuje nie tylko ściśle naukową działalność, ale także m.in. projekty w zakresie edukacji i zdrowia publicznego. Przygotowaliśmy wspólnie z innymi onkologicznymi towarzystwami naukowymi polską wersję protokołu badania patomorfologicznego College of American Pathologists, który jest obecnie wdrażany w polskich jednostkach onkologicznych. Z satysfakcją obserwujemy wzrost aktywności naukowej polskich onkologów, mierzony liczbą prezentacji naukowych i publikacji w renomowanych czasopismach o międzynarodowym zasięgu — staramy się promować je w naszym Newsletterze i w formie specjalnego wydawnictwa "Polacy na ASCO”.

Prof. ET: Proszęo przedstawienie działań w zakresie wspierania badań naukowych.

Prof. JJ: Dzięki dotacji firmy Roche udało nam się zorganizować konkurs grantów w dziedzinie nauk podstawowych. W 1. edycji przyznaliśmy 5 grantów na łączną kwotę 250000 zł.W tym roku, na 2. edycję tego konkursu, wspieraną dodatkowo przez firmę Astra Zeneca, wpłynęło kilkanaście ciekawych projektów - wyniki ogłosimy 28 czerwca, podczas naszego Walnego Zebrania Członków PTO. Promujemy działalność naukową, informując na bieżąco naszych członków o najważniejszych wydarzeniach i odkryciach w dziedzinie onkologii. Corocznie przyznajemy nasze nagrody naukowe — imienia Hilarego Koprowskiego i Franciszka Łukaszczyka, a co 4 lata — nagrodę imienia Sobolewskich. Na internetowej stronie Towarzystwa znajduje się aktualizowana baza prowadzonych w Polsce badań klinicznych w dziedzinie onkologii - korzystają z niej zarówno lekarze, jak i pacjenci. Działalność naukową staramy się także wspierać, dofinansowując udział naszych Członków w szkoleniach dotyczących pisania doniesień naukowych oraz statystyki medycznej, a także w wyjazdach na konferencje naukowe i pobyty stypendialne.

Prof. ET: Działalność Towarzystwa znajdowała znaczący rozgłos medialny.

Prof. JJ: Już w pierwszych miesiącach kadencji stworzyliśmy profesjonalną dwujęzyczną internetową stronę Towarzystwa, która stała się ważnym źródłem wiedzy i informacji związanych z onkologią w Polsce i na świecie. Regularnie co 2 tygodnie ukazuje się elektroniczny Newsletter PTO, który dociera do około 2000 odbiorców — oprócz członków PTO także dziennikarzy, polityków i innych osób, które interesują się onkologią. Organizujemy duże konferencje prasowe, jesteśmy obecni w prasie, radio i telewizji. O naszych inicjatywach informuje regularnie kilka czasopism, m.in. Nowotwory J Oncol, Puls Medycyny, Menedżer Zdrowia i Rynek Zdrowia. Ważną rolę w promocji onkologii odgrywa także wspomniana wcześniej„_Letnia Akademia Onkologiczna” dla dziennikarzy. Podczas organizowanych przez nas większych spotkań naukowych organizujemy stoisko PTO, na którym można znaleźć informacyjne i promocyjne materiały. Patronujemy ogólnopolskim akcjom medialnym i edukacyjnym, np. „Mam haka na raka” czy „Rak. To się leczy!”. 
Prof. ET: Na łamach Nowotworów nie może zabraknąć pytania o sprawy edytorskie.

Prof. JJ: Nowotwory J Oncol jest jednym z najstarszych czasopism onkologicznych w skali świata - w ubiegłym roku uroczyście obchodziliśmy jego 90-lecie. Z tej okazji odbyła się okolicznościowa sesja oraz historyczna wystawa. Podczas obecnej kadencji powołaliśmy grono redaktorów pomocniczych w zakresie poszczególnych dziedzin oraz nową Radę Redakcyjną, co nieco ułatwiło pracę Redaktorowi Naczelnemu, a także zmierza do podniesienia prestiżu pisma i jego naukowej rangi. Przed wydaniem każdego zeszytu wysyłamy do wszystkich prenumeratorów zapowiedź jego zawartości pocztą elektroniczną. Udało nam się także znaleźć profesjonalnego wydawcę - renomowaną gdańską firmę Via Medica, co odciążyło Redakcję od wielu administracyjnych obowiązków i znacznie ułatwiło wydawanie Nowotworów. Towarzyszyło temu nadanie pismu nowej, atrakcyjnej szaty graficznej i stworzenie aktywnej strony internetowej. Nowy system prenumeraty sprawia, że obecnie Nowotwory docierają do wszystkich naszych Członków. Z okazji dużych spotkań onkologicznych przygotowujemy cieszące się sporym zainteresowaniem specjalne zeszyty czasopisma. Z inicjatywy Redaktora Naczelnego Nowotworów ukazują się także wartościowe opracowania historyczne, czego przykładem jest wydana niedawno, unikatowa w skali świata, bibliografia promieniowania X od chwili jego wykrycia w 1896 roku, autorstwa wieloletniego Zastępcy Redaktora Naczelnego Nowotworów - Prof. Richarda Moulda. Korzystając z okazji, chciałbym Panu bardzo podziękować za ogromny, wieloletni wysiłek w działaniu na rzecz naszego pisma.

Prof. ET: Oprócz niewątpliwych sukcesów mogły być też niepowodzenia - jakie?

Prof. JJ: Na szczęście nie było ich wiele. Kilku projektów nie udało się dokończyć. Przykładem jest uporządkowanie diagnostyki molekularnej nowotworów w Polsce. Propozycję odpowiednich uregulowań prawnych złożyliśmy w Ministerstwie Zdrowia ponad 3 lata temu, niestety dotychczas nie podjęto $w$ tej sprawie żadnych decyzji. Wbrew zamierzeniom nie udało nam się także uruchomić niezbędnych e-learningo- wych form szkolenia zawodowego oraz cyklu regionalnych naukowych spotkań z udziałem patomorfologów. Mam nadzieję, że projekty te zrealizuje następny Zarząd.

Prof. ET: Pozostając w roli Past-Prezesa, jakie miałby Pan wskazówki i sugestie dla nowego Zarządu - co kontynuowaćijak, czego zaniechać, jakie powinny być priorytety?

Prof. JJ: Funkcja Przewodniczącego Zarządu Głównego to wielki zaszczyt, ale i ogrom obowiązków. Na szczęście w swojej pracy miałem silne wsparcie zarówno ze strony sekretarza Zarządu Głównego prof. Marzeny Wełnickiej-Jaśkiewicz, jak i skarbnika dr. hab. Jacka Zielińskiego oraz grona Koleżanek i Kolegów z Zarządu Głównego. W przyszłej kadencji warto jednak pomyśleć nad powierzeniem odpowiedzialności za poszczególne projekty większej liczbie osób, co na pewno usprawni pracę i podniesie jej jakość. Liczę, że moim następcom uda się doprowadzić do wdrożenia naszego głównego projektu — Strategii Walki z Rakiem w Polsce; będzie to jednak wymagało wielkiego wysiłku. Myślę, że powinny powstać również nowe inicjatywy i formy działania, które pozwolą jeszcze lepiej pełnić naszą misję.

Prof. ET: Po uwolnieniu od codziennych ogromnych zobowiq̨zań i obciqzżeń wynikających z prezesowania - w jakim kierunku skieruje Pan Profesor swoją niezwykłq energię i skuteczność działania — jakie ma Pan plany na najbliższe lata?

Prof. JJ: Zgodnie ze statutem przez około połowę następnej kadencji pozostanę w składzie Zarządu Głównego, starając się wspierać jego pracę; kilka projektów chciałbym osobiście dokończyć. Cieszę się jednak, że będę mógł więcej czasu poświęcić mojej pracy naukowej i dydaktycznej w Gdańskim Uniwersytecie Medycznym, co obiecałem moim współpracownikom. Liczę, że będę mógł także zrealizować kilka — odkładanych od lat — naukowych i wydawniczych zamierzeń. Może wreszcie znajdę trochę więcej czasu na życie rodzinne i towarzyskie, które nieuchronnie nieco ucierpiało w ciągu ostatnich 4 lat, a także na realizację moich pozazawodowych pasji.

Prof. ET: Dziękuję za rozmowę. 